\title{
ZINC PRIMING OF MAIZE SEED ENHANCES ROOT TO SHOOT Zn TRANSLOCATION BUT NOT OF ANALOGOUS HEAVY METALS
}

\author{
A. Kiran ${ }^{1 *}$, A. Wakeel ${ }^{2}$, R. Ishaq ${ }^{1}$, R. Mubaraka ${ }^{2,3}$, M. Ishfaq ${ }^{2,4}$ and A. Mahmood ${ }^{5}$ \\ ${ }^{1}$ Department of Botany, University of Agriculture, Faisalabad-38040, Pakistan \\ ${ }^{2}$ Institute of Soil and Environmental Sciences, University of Agriculture, Faisalabad-38040, Pakistan \\ ${ }^{3}$ Cologne Biocenter, Institute of Botany, University of Cologne, Cologne, Germany \\ ${ }^{4}$ Department of Plant Nutrition, College of Resources and Environmental Sciences, China Agricultural University, \\ Beijing-100193, China \\ ${ }^{5}$ Soil and Plant Nutrient Unit, Brunei Agricultural Research Centre, BG 1121, Brunei Darussalam \\ Corresponding author's email: aysha.kiran@uaf.edu.pk
}

\begin{abstract}
Soil contaminated with heavy metals is considered a leading environmental concern as they are translocated to harvestable part of plant and ultimately influence animals and human health. Pre-germination metabolic processes stimulated by seed priming with mineral nutrient may facilitates the availability of that particular nutrient under adverse soil conditions. Seed priming with zinc $(\mathrm{Zn})$ impact on $\mathrm{Zn}$ and heavy metals, for instance, cadmium $(\mathrm{Cd})$ and nickel $(\mathrm{Ni})$, uptake and their translocation within plant was evaluated in this research study. Seeds of maize were hydro-primed and $\mathrm{Zn}$-primed $\left(\mathrm{ZnSO}_{4}\right.$ solution) before sowing. Soil was amended with heavy metals, namely $\mathrm{Cd}$ and $\mathrm{Ni}$ and seedling was harvested after twenty days of sowing. There was no considerable treatment effect found in the various plant morphological and physiological attributes. However, interestingly, on the one hand, seed priming with $\mathrm{Zn}$ enhanced its uptake and distribution within plant; on the other hand, reduction in root-to-shoot translocation of $\mathrm{Cd}$ and $\mathrm{Ni}$ was observed. As a result, seed priming with $\mathrm{Zn}$ is not only an advantageous approach to improve $\mathrm{Zn}$ nutrition but also valuable to hinder the translocation of heavy metals and ultimately it can suppress inclusive deleterious impacts on human health.
\end{abstract}

Key words: Contaminated Soils; Heavy Metals; Seed Priming; Zea mays; Zinc

Published online December 18, 2020

\section{INTRODUCTION}

Seed priming with mineral nutrients is an approach to improve the seed nutrient contents in conjunction with the priming effect per se obviously to increase the seed quality for better germination and the seedling establishment. The process of seed priming makes a seed more resilient prior to an abiotic stress exposure. In detail, pre-germination, metabolic processes of seed are stimulated, accordingly makes it ready for radicle protrusion and eventually improve seed potency in the course of germination and emergence. It helps the repair of membranes and also boosts the activity of the antioxidant system (Paparella et al., 2015; Qayyum et al., 2018). Furthermore, $\mathrm{Zn}$ priming of seed may accelerate $\mathrm{Zn}$ transportation and eventually improve its uptake from soils, which ultimately strengthen plant growth, yield and $\mathrm{Zn}$ contents in the grains (Mondal and Bose, 2019; Rashid et al., 2019).

Zinc performs a substantial role in energy transfer reactions in plants, photosynthesis, bio-membrane stability, structural activities, and catalytic protein synthesis (Alloway, 2008; Hajiboland and Amirazad, 2010). It can also detoxify reactive oxygen species (ROS) to mitigate the oxidative stress (Feigl et al., 2015).
Furthermore, it involves as a cofactor for the stimulation of more than 300 enzymes, accomplish a substantial part in water transport and uptake by reducing effect of abiotic stresses like heat and salt stresses antagonistically (Kasim, 2007; Sbartai et al., 2011). Zinc deficiency ranks $5^{\text {th }}$ amongst the reasons of deaths and illnesses in human, especially in developing countries (WHO, 2009). Likewise, a substantial number of people in Pakistan especially women and children are $\mathrm{Zn}$ deficient, according to our most recent survey more than $30 \%$ of the investigated Faisalabad region of Pakistan found $\mathrm{Zn}$ deficient in the soil, wheat grain along with humans (unpublished data).

Heavy metals are toxic metals and considerable reduce plant growth and yield even at low concentration. The plant uptake them from contaminated soils, translocate them from root-to-shoot and ultimately become the part of the harvestable portion of the plant. In contaminated soils, $\mathrm{Cd}$ has appeared as one of the critical hazards not only to environmental stability as well as to global food security; as once it amasses in the soil remains there for a longer period of time. Therefore, it can certainly become the part of the food chain when existing in agricultural soils (Simmons et al., 2003). Reduced uptake of other essential plant nutrients, for example, N, P, K 
along with $\mathrm{Ca}$ and $\mathrm{Mg}$ was found and it also suppresses their translocation from root to shoot (Wang et al., 2014; Yourtchi and Bayat, 2013), consequently, adversely affects crop growth and yield (de Souza Guilherme et al., 2015; Chen et al., 2017; Shiyu et al., 2020). Furthermore, $\mathrm{Ni}$ toxicity is also becoming an emerging concern as its availability in soils are increasing especially in urban areas as a result of continuous application of polluted sewage water. Same like Cd, higher concentration of Ni can also reduce the availability of other plant nutrients, for instance, substitute iron (Fe) and $\mathrm{Zn}$ in soil solution (Sabir et al., 2011) or nitrogen (N) and phosphorus (P) (Santos et al., 2019).

The Cd translocation in plants can be suppressed if the sufficient amount of $\mathrm{Zn}$ is applied to $\mathrm{Cd}$ contaminated soils (Ishfaq et al., 2018; Ma et al., 2020) Due to their competitive interaction of $\mathrm{Cd}$ and $\mathrm{Zn}$ uptake via plant roots, they are transported by the same carrier proteins of plasma membrane (Köleli et al., 2004) or expression regulation specific ZIP genes (De Oliveira et al., 2020; Martha-Paz et al., 2019; Palusińska et al., 2020). Most recently, it is revealed that $\mathrm{Zn}$ efficient plants can reduce $\mathrm{Cd}$ uptake, its root to shoot translocation and finally accumulation in grains (Sarwar et al., 2010; Qaswar et al., 2017;) or just suppress its accumulation in edible part of the plant (Ishfaq et al., 2018). Nevertheless, little is known about the impact seed priming with $\mathrm{Zn}$ in the uptake and translocation of heavy metals, for instance, $\mathrm{Cd}$ and $\mathrm{Ni}$ from root-to-shoot (Murtaza et al., 2017).

As maize plants are able to store $\mathrm{Cd}$ and $\mathrm{Ni}$, become adaptable for metals and show the reduction in growth (Gallego et al., 2012). It is evident that such heavy metals may share $\mathrm{Zn}$ uptake systems of plant cells. Therefore, this research study was planned with the objective to evaluate the consequence of Zn-primed maize seed in the uptake and its root to shoot translocation for $\mathrm{Zn}$ along with $\mathrm{Cd}$ and $\mathrm{Ni}$. The ultimate objectives of the intended study were to explore: i) the beneficial aspect of $\mathrm{Zn}$ seed priming on $\mathrm{Zn}$ uptake from soil and its distribution within plant ii) the impact of seed priming with $\mathrm{Zn}$ on uptake and root to shoot translocation of heavy metals, namely $\mathrm{Cd}$ and $\mathrm{Ni}$ from the contaminated soil.

\section{MATERIALS AND METHODS}

Experimental layout: A greenhouse experiments was carried out in this research study in pots with one $\mathrm{kg}$ soil per pot placed at the Botanic garden, University of Agriculture, Faisalabad-Pakistan to evaluate the consequence of seed priming with $\mathrm{Zn}$ in the form of $\mathrm{ZnSO}_{4} .7 \mathrm{H}_{2} \mathrm{O}$ (analytical grade) in $\mathrm{Zn}$ and heavy metals, for instance, $\mathrm{Cd}$ and $\mathrm{Ni}$ uptake from the soil and their root to shoot translocation. Basic analysis of soil used in experiment, for instance, ECe, $\mathrm{pH}$, texture, $\mathrm{Zn}$ and $\mathrm{Cd}$ concentration is presented in Table 1. Seeds of Maize (Zea mays) variety Malka-2016 was obtained from the Ayub
Agricultural Research Institute, Faisalabad, Pakistan for assessment of treatments.

Table 1. Physicochemical characteristics of the soil used in the experiment.

\begin{tabular}{|c|c|c|}
\hline Parameter & Unit & Value \\
\hline $\mathrm{pH}^{\mathrm{a}}$ & --- & 7.16 \\
\hline $\mathrm{EC}_{\mathrm{e}}^{\mathrm{a}}$ & $\mathrm{dS} \mathrm{m}^{-1}$ & 1.38 \\
\hline Sand, Silt, Clay ${ }^{b}$ & $\%$ & $53,24,23$ \\
\hline Textural class ${ }^{\mathrm{c}}$ & --- & Sandy clay loam \\
\hline Saturation percentage $\mathrm{d}^{\mathrm{d}}$ & $\%$ & 33 \\
\hline Organic matter & $\mathrm{g} \mathrm{kg}^{-1}$ & 7.2 \\
\hline $\mathrm{Zn}^{\mathrm{f}}$ & $\mathrm{mg} \mathrm{kg}{ }^{-1}$ & 0.91 \\
\hline $\mathrm{Cd}^{\mathrm{f}}$ & $\mathrm{mg} \mathrm{kg}^{-1}$ & 0.14 \\
\hline \multicolumn{3}{|c|}{ a. Measured in $1: 1$ soil to water } \\
\hline \multicolumn{3}{|c|}{ b. Hydrometer method (Page et al., 1982) } \\
\hline \multicolumn{3}{|c|}{ c. USDA classification } \\
\hline \multicolumn{3}{|c|}{$\begin{array}{l}\text { d. Determined by soil saturated paste and oven drying } \\
\text { method }\end{array}$} \\
\hline \multicolumn{3}{|c|}{ e. Walkley-Black method (De Vos et al., 2007) } \\
\hline \multicolumn{3}{|c|}{ f. AB-DTPA extractable (Soltanpour, 1985) } \\
\hline
\end{tabular}

There were two sets of treatments, first with $\mathrm{Zn}$ primed and second with water primed seeds. Each of the sets had control (without soil application of $\mathrm{Zn}, \mathrm{Cd}$ and $\mathrm{Ni}$ and mentioned as $\mathrm{CK}$ for water primed or for $\mathrm{Zn}$ primed seeds), soil $\mathrm{Zn}$ application (10 $\mathrm{mg} \mathrm{kg}^{-1}$ soil mentioned as $\mathrm{Zn})$, soil $\mathrm{Cd}$ application (17 $\mathrm{mg} \mathrm{kg}^{-1}$ soil mentioned as $\left.\mathrm{Cd}\right)$ and $\mathrm{Ni}\left(9 \mathrm{mg} \mathrm{kg}^{-1}\right.$ soil mentioned as $\left.\mathrm{Ni}\right)$. The application rate of $\mathrm{Zn}$ was as per recommended dose whereas $\mathrm{Cd}$ and $\mathrm{Ni}$ were applied equivalent to that of the $\mathrm{Zn}$ application rate. The experiment was laid out as stated by two-way factorial design and each treatment was replicated four times, in this fashion total thirty-two experimental units.

Seed priming was done by soaking the maize seeds for 16 hours in distilled water and $0.5 \mathrm{mM}$ $\mathrm{ZnSO}_{4} .7 \mathrm{H}_{2} \mathrm{O}$ (144 mg L-1 DW) solution separately. After soaking, six primed seeds were sown in each pot reserved in a control greenhouse. A basal dose of NPK fertilizers was applied in each pot equivalent to 200,120 and $80 \mathrm{~kg}$ $\mathrm{ha}^{-1}$, respectively using urea, diammonium phosphate and potassium sulfate fertilizers. Soil was contaminated with heavy metal as stated above one week before the time of sowing. After contaminating soil thorough mixing was done to attain uniform distribution of nutrients and heavy metals.

Crop husbandry and harvesting: After the establishment, three seedlings as biological replicates were maintained in each pot. Irrigation of pots were done on water requirements of $60 \%$ water holding capacity of soil. Maize seedling was harvested after twenty days of sowing to test treatment effect. Plant growth traits i.e. dry and fresh shoot and root weight was measured with digital weighing balance. Plant physiological attributes, namely transpiration rate, photosynthesis rate, stomatal 
conductance and sub-stomatal $\mathrm{CO}_{2}$ concentration were recorded before harvesting by using digital Infrared gas analyzer. SPAD 502 P meter was used to measure spectral plant analysis diagnostic (SPAD) value which reflect the chlorophyll contents. For determination of physiological attributes, the youngest fully expanded leaf was analyzed three times. The process was carried out for all three plants in each pot and averages from each pot was deliberated as technical replicates.

Determination of concentration and translocation of Zn, Cd and Ni: Root and shoot of maize seedling were processed further to analyze the concentrations of $\mathrm{Zn}, \mathrm{Cd}$ and $\mathrm{Ni}$ according to the prescribed protocol (Hseu, 2004). In brief, fine ground root and shoot samples (oven dried at $70+5{ }^{\circ} \mathrm{C}$ till constant weight) were digested in the di-acid mixture with a ratio of $2: 1\left(\mathrm{HNO}_{3}: \mathrm{HClO}_{4}\right)$ at $250 \pm 5{ }^{\circ} \mathrm{C}$ before mixing it for one night. Dense fumes (whitish) of perchloric acid were observed in tubes and this digestion process was continued for further 30 minutes. After that samples were diluted with distilled water up to $25 \mathrm{~mL}$ volume and filtered using Whatman 42 filter paper. $\mathrm{Zn}, \mathrm{Cd}$ and $\mathrm{Ni}$ concentrations were determined in samples using the atomic absorption spectrophotometer (Hitachi Polarized Zeeman AAS, Z-8200, Japan) and drawing calibration curve with working standards. The translocation factor for $\mathrm{Zn}, \mathrm{Cd}$ and $\mathrm{Ni}$ translocation from root-to-shoot was calculated by using following formula:

Translocation factor

$$
=\frac{(\text { Shoot dry Wt. } \times \mathrm{Zn}, \mathrm{Cd} \text { or Ni Conc. in shoot })}{\text { (Root dry Wt. } \times \mathrm{Zn}, \mathrm{Cd} \text { or Ni Conc. in root) }}
$$

Statistical Analysis: All collected data from each experimental unit was analyzed by statistical technique (Johnson and Bhattacharyya, 2019) by using Statistix 9®) for Windows (Analytical Software, Tallahassee, USA). Two-way analysis of variance (ANOVA) subsequently the LSD test was used at $P \leq 0.05$ for the evaluation of treatment effect.

\section{RESULTS}

Effect of seed priming on morphological attributes: There was no considerable treatment effect was found in fresh root weight of primed seed, however dry root weight improved with $\mathrm{Zn}$ priming. Maximum dry root weight was found in $\mathrm{Zn}$ primed $\mathrm{CK}$ (2.55 g) and is significantly $(P \leq$ $0.05)$ reduced in distilled water primed $\mathrm{Cd}$ contaminated condition $(1.04 \mathrm{~g})$. There was no statistically significant difference found for fresh and dry shoot weight of $\mathrm{Zn}$ primed treatments $(P \leq 0.05)$; however, maximum fresh shoot weight was $3.42 \mathrm{~g}$ and dry shoot weight of $0.51 \mathrm{~g}$ was found in water primed $\mathrm{Ni}$ contaminated treatment (Table 2).

Effect of seed priming on physiological traits: The collected data regarding physiological traits was found in the irregular pattern with seed priming and contamination of soil with heavy metals. Maximum photosynthesis rate was noticed under water primed CK treatment $(6.17 \mu \mathrm{mol}$ $\mathrm{CO}_{2} \mathrm{~m}^{-2} \mathrm{~S}^{-1}$ ) and it was found the minimum water primed $\mathrm{Cd}$ contaminated treatment $\left(1.99 \mu \mathrm{mol} \mathrm{CO} \mathrm{Cm}^{-2} \mathrm{~S}^{-1}\right)$. In case of $\mathrm{Zn}$ primed, the rate of photosynthesis was found higher in $\mathrm{Zn}$ primed $\mathrm{Ni}$ contaminated soil $\left(4.40 \mu \mathrm{mol} \mathrm{CO}_{2}\right.$ $\left.\mathrm{m}^{-2} \mathrm{~S}^{-1}\right)$. The maximum rate of transpiration was observed in the leaves of water primed $\mathrm{Ni}$ contaminated treatment ( $1.51 \mathrm{mmol} \mathrm{H}_{2} \mathrm{O} \mathrm{m}^{-2} \mathrm{~S}^{-1}$ ), while the minimum was detected in $\mathrm{Zn}$ primed $\mathrm{CK}\left(0.68 \mathrm{mmol}_{2} \mathrm{O} \mathrm{m}^{-2} \mathrm{~S}^{-1}\right)$. In $\mathrm{Zn}$ primed $\mathrm{Cd}$ contaminated treatment stomatal conductance was noticed higher $\left(0.04 \mathrm{mmol} \mathrm{H}_{2} \mathrm{O} \mathrm{m} \mathrm{m}^{-2} \mathrm{~S}^{-1}\right)$ relatively other treatments while it was found the minimum in $\mathrm{Zn}$ primed $\mathrm{Ni}$ contaminated treatment and water primed $\mathrm{Zn}$ applied soil. Sub-stomatal $\mathrm{CO}_{2}$ concentration was also affected by priming; it was observed significantly $(P \leq 0.05)$ higher in Zn primed CK $\left(472.3 \mu \mathrm{mol} \mathrm{mol}^{-1}\right)$ as compared to all other treatments (Figure 1). The data regarding SPAD value was also found non-significant in different treatments and seed priming conditions $(P \leq 0.05)$ (Table 2$)$.

Effect of Zn seed priming on uptake and translocation of $\mathrm{Zn}, \mathrm{Cd}$ and Ni: After analysis of plant root and shoot samples, there was the considerable treatment effect was found in the pattern of $\mathrm{Zn}, \mathrm{Cd}$ and $\mathrm{Ni}$ uptake and translocation within plant (Figure 2 \& 3). Maximum $\mathrm{Zn}$ concentration $\left(16.90 \mathrm{mg} \mathrm{kg}^{-1} \mathrm{DW}\right)$ was found in the shoot of $\mathrm{Zn}$ primed seeds under $\mathrm{Ni}$ contaminated soil and it was found minimum $\left(2.58 \mathrm{mg} \mathrm{kg}^{-1} \mathrm{DW}\right)$ in $\mathrm{Cd}$ contaminated soil where water primed seed were sown. In shoot, overall $\mathrm{Zn}$ concentration improved 48.80, 82.62 and $80.94 \%$ with $\mathrm{Zn}, \mathrm{Cd}$ and $\mathrm{Ni}$ application in $\mathrm{Zn}$ primed seed as compare to the water primed (Figure $2 \mathrm{~A}$ ). In root $\mathrm{Zn}$ concentration increased $(7.29 \%)$ in $\mathrm{Cd}$ contaminated $\mathrm{Zn}$ primed treatment as compare with $\mathrm{Cd}$ contaminated water primed seed. Non-significant effect of treatments was found @ $P$ $\leq 0.05$ in other treatments (Figure 2D).

In contrast to $\mathrm{Zn}, \mathrm{Cd}$ concentration found higher in water primed treatments. In shoot maximum $\mathrm{Cd}$ concentration $\left(36.20 \mu \mathrm{gkg}^{-1} \mathrm{DW}\right)$ was found in $\mathrm{Cd}$ contaminated water primed treatment and with $\mathrm{Zn}$ priming it was significantly reduced $(6.86 \%)$. In other treatments, there was no significant variation was found $(P \leq 0.05)$ (Figure 2B). In root, $\mathrm{Cd}$ concentration also increased (40.35 $\left.\mu \mathrm{g} \mathrm{kg}^{-1} \mathrm{DW}\right)$ with $\mathrm{Cd}$ contamination, however, in $\mathrm{Zn}$ primed seed it was significantly reduced $(5.32 \%)$ as compared to water primed. In other treatments, the pattern was found statistically non-significant $(P \leq 0.05)$ (Figure 2E).

Like $\mathrm{Cd}$, Ni concentration reduced in the shoot of maize seedling with $\mathrm{Zn}$ priming as compared to water primed seed. Ni concentration was found higher in $\mathrm{Ni}$ contaminated treatment; this pattern was found higher in water primed seed; however, it was reduced with $\mathrm{Zn}$ priming. Maximum Ni concentration $\left(94.36 \mu \mathrm{g} \mathrm{kg}^{-1} \mathrm{DW}\right)$ 
was found in the shoot of $\mathrm{Ni}$ contaminated water primed treatment and with $\mathrm{Zn}$ priming it was reduced 80.60, 106 and $33.61 \%$ in $\mathrm{CK}, \mathrm{Zn}$ application and $\mathrm{Ni}$ contamination, respectively (Figure $2 \mathrm{C}$ ). In roots $\mathrm{Ni}$ concentration also found the maximum in $\mathrm{Ni}$ contaminated water primed treatment (58.52 $\left.\mathrm{g} \mathrm{kg} \mathrm{k}^{-1} \mathrm{DW}\right)$ and it was reduced to 21.44 $\mu \mathrm{g} \mathrm{kg}^{-1}$ with $\mathrm{Zn}$ priming. In other treatment reduction was found non-significant (Figure 2F).
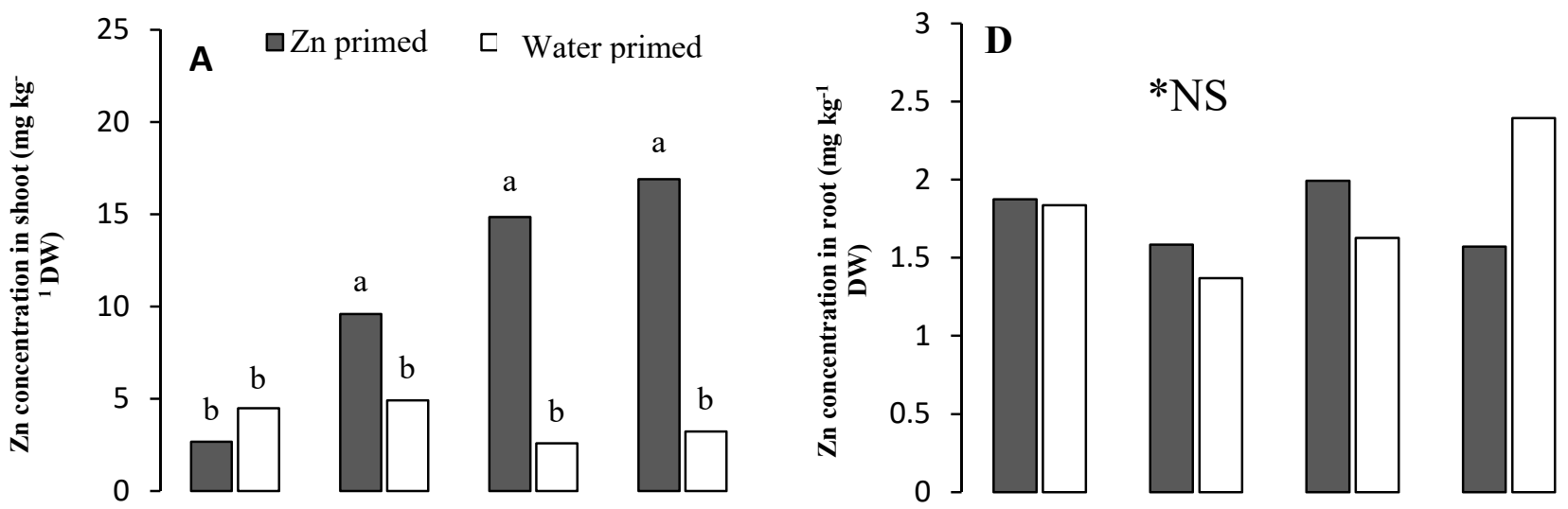

B
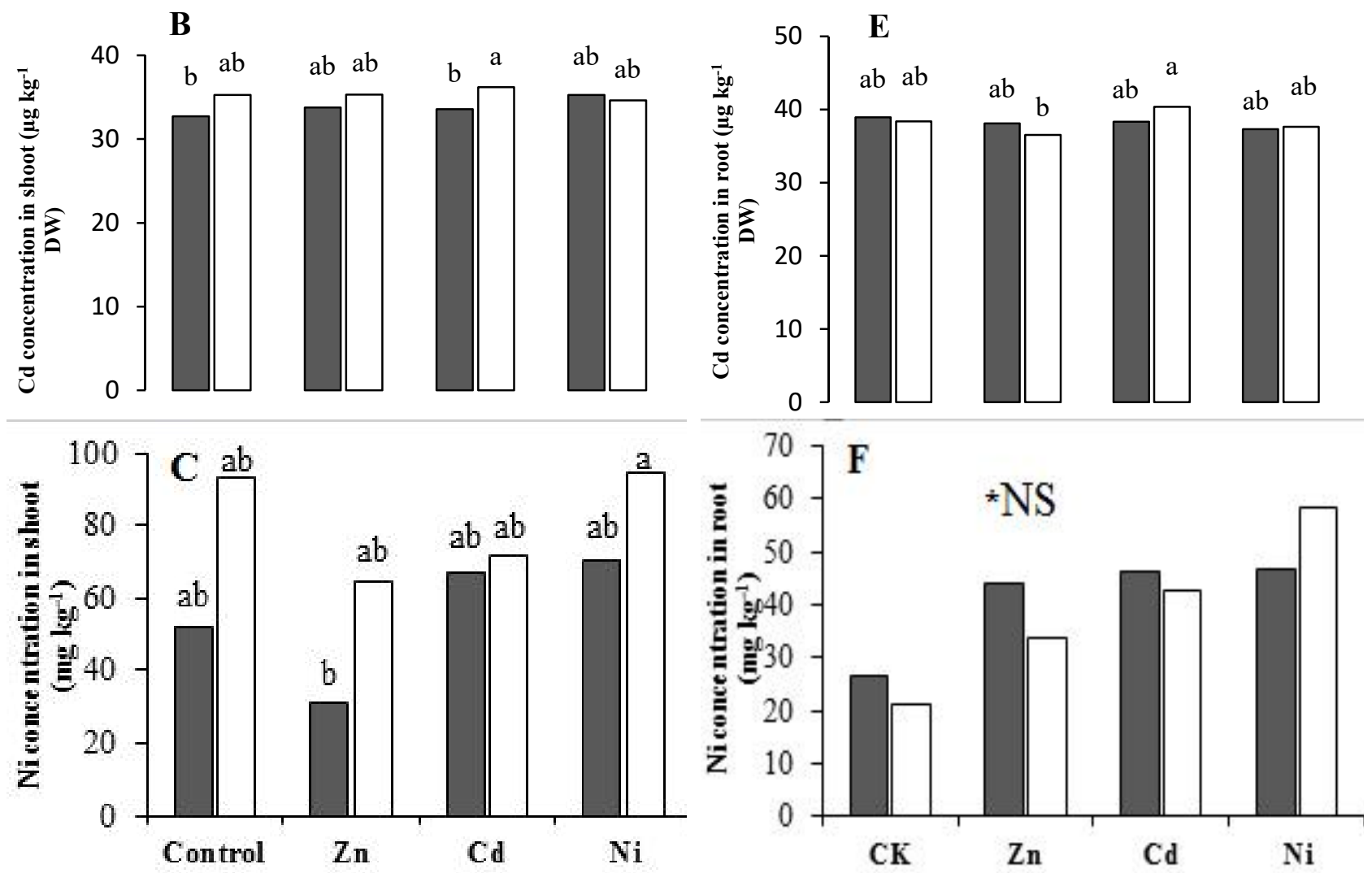

Figure 2. The effect of $\mathrm{Zn}$ and water seed priming on shoot and root $\mathrm{Zn}$ and heavy metals, namely Cd and Ni uptake and translocation via maize (Zea mays) seedling in contaminated soil. Zn concentration in shoot (A), Cd concentration in shoot (B), Ni concentration in shoot $(C), \mathrm{Zn}$ concentration in root $(\mathrm{D}), \mathrm{Cd}$ concentration in root $(\mathrm{E})$, and $\mathrm{Ni}$ concentration in root (F). Column shows mean of four replicates while bars shows standard deviation ( \pm ). The mean sharing similar letter (s) do not differ significantly $(P \leq 0.05)$ according to $L S D(Z n) 2.78,1.59 ;$ Cd 1.31, 1.67 and $\mathrm{Ni} 24.65,18.44$ for shoot and root, respectively). *NS= No significant treatment effect was detected

\section{DISCUSSION}

The impact of seed priming with $\mathrm{Zn}$ was evaluated in this study with reference to its uptake and distribution within plant along with its influence on the root to shoot translocation of heavy metals $(\mathrm{Cd}$ and $\mathrm{Ni}$ ) in contaminated soils. Considering plant growth mentioned as shoot and root weights, asymmetrical treatment effects 
were found among various treatments. Maximum root dry weight in $\mathrm{Zn}$ primed $\mathrm{CK}$ treatment was recorded as compared with soil $\mathrm{Zn}$ applied treatment. Maximum fresh shoot and dry shoot weight were recorded in the $\mathrm{Zn}$ applied $\mathrm{Ni}$ contaminated soils. As the low doses of these metals were applied, therefore a symmetrical difference between different treatments were not expected for plant growth attributes. However, similar finding is revealed by a number of researchers in various crop species (Aremu and Meshitsuka, 2005; Sabir et al., 2011; Syam et al., 2016; Chen et al., 2017). Data regarding physiological traits showed that photosynthesis rate was less in water primed $\mathrm{Cd}$ contaminated soil and $\mathrm{Zn}$ priming might reduce the deleterious impact of $\mathrm{Ni}$ contamination on photosynthesis rate. Such a reduced rate of photosynthesis in contaminated soil under water primed seed might be due to the accretion of heavy metals primarily in photosynthetically active (transpiring) leaves. Similarly, improvement in sub-stomatal $\mathrm{CO}_{2}$ concentration and stomatal conductance with $\mathrm{Zn}$ priming in contaminated soil was observed (Figure 2). Afzal et al. (2013, 2015) previously reported positive effect of $\mathrm{Zn}$ priming on physiological performance of maize.

Improved shoot $\mathrm{Zn}$ contents 48.80, 82.62 and $80.94 \%$ due to $\mathrm{Zn}$ seed priming under soil $\mathrm{Zn}, \mathrm{Cd}$ and $\mathrm{Ni}$ treatments may be attributed to better stand establishment and root architecture as revealed (Mohsin et al., 2014). Such improvement in $\mathrm{Zn}$ concentration in the plant with $\mathrm{Zn}$ application has also been reported by other researchers as well (Ishfaq et al., 2018; Joy et al., 2015; Cioccio et al., 2017; Rizwan et al., 2019). In addition, root $\mathrm{Zn}$ concentration increased $(7.29 \%)$ in Cd contaminated $\mathrm{Zn}$ primed treatment (Figure $2 \mathrm{E}$ ) showing that $\mathrm{Zn}$ transporters family accelerated by $\mathrm{Zn}$ priming and restrict the $\mathrm{Cd}$ translocation within plants due to the availability of $\mathrm{Zn}$ in the soil solution (Ishfaq et al., 2018) or up-regulation of root specific ZIP genes involved in its root to shoot translocation (Palusińska et al., 2020). Reduced translocation due to $\mathrm{Zn}$ priming was also observed (Table 2 ). For instance, the $\mathrm{Cd}$ uptake by plant root can be minimized if sufficient level of $\mathrm{Zn}$ is applied to $\mathrm{Cd}$ contaminated soils (Venkatachalam et al., 2017; Ishfaq et al., 2018; Rizwan et al., 2019), due to their competitive interaction in uptake via roots because they are transported by the same carrier membrane proteins (Köleli et al., 2004; Moustakas et al., 2011; Sarwar et al., 2010). Murtaza et al. (2017) also observed antagonistic effect of $\mathrm{Zn}$ as reduction in $\mathrm{Cd}$ concentration in cereal plants tissues with a significant increase in $\mathrm{Zn}$ concentration.

Being an essential element plants can take up $\mathrm{Ni}$ easily if it is present in the soil and its beneficial impact can also be observed in plants. However, in highly contaminated soils it may have toxic effects on plant growth (Santos et al., 2019). In present study, low level of $\mathrm{Ni}$ was used to understand the impact of $\mathrm{Zn}$ priming on $\mathrm{Ni}$ uptake. $\mathrm{Zn}$ priming decreased the $\mathrm{Ni}$ content in shoot; however, it was not significant (Figure 2), therefore further studies with higher $\mathrm{Ni}$ contamination are still remains open. However, it can be assumed that unlike $\mathrm{Cd}$ transport, $\mathrm{Ni}$ uptake is not directly dependent on the $\mathrm{Zn}$ uptake system and may have its own system which can even work efficiently in the presence of Zn (Mohseni et al., 2019; Yusuf et al., 2011), though specific underlying mechanisms of Ni uptake and transportation in plant still remains open to uncover. Nevertheless, increased $\mathrm{Zn}$ uptake, its competing trend with $\mathrm{Cd}$ for binding to critical cell constituents and translocation in $\mathrm{Cd}$ contaminated soils also indicate $\mathrm{Zn}$ specific uptake system (Köleli et al., 2004; Palusińska et al., 2020).

The schematic mechanism of our research findings for the uptake and root to shoot translocation of $\mathrm{Cd}$ and Ni mediated by $\mathrm{Zn}$ seed priming is demonstrated in below given diagram (Figure 3) adapted from Banakar et al., (2017) and DalCorso et al. (2019). Banakar et al., (2017) and DalCorso et al. (2019). However, various underlying molecular mechanisms, selective redistribution of heavy metals, their uptake, translocation within plant via specific transport systems, and other intermediated signaling pathways need to be further elucidated for biofortification of plants (Page and Feller, 2015). The most recent advances in the omics approaches, for instance, transcriptomics, proteomics, and ionomics ultimately required to significantly improve heavy metal tolerance in crop plants and can also be beneficial for revealing the underlying molecular regulatory systems in the translocation of heavy metals mediated by $\mathrm{Zn}$ seed priming (Singh et al., 2016). 


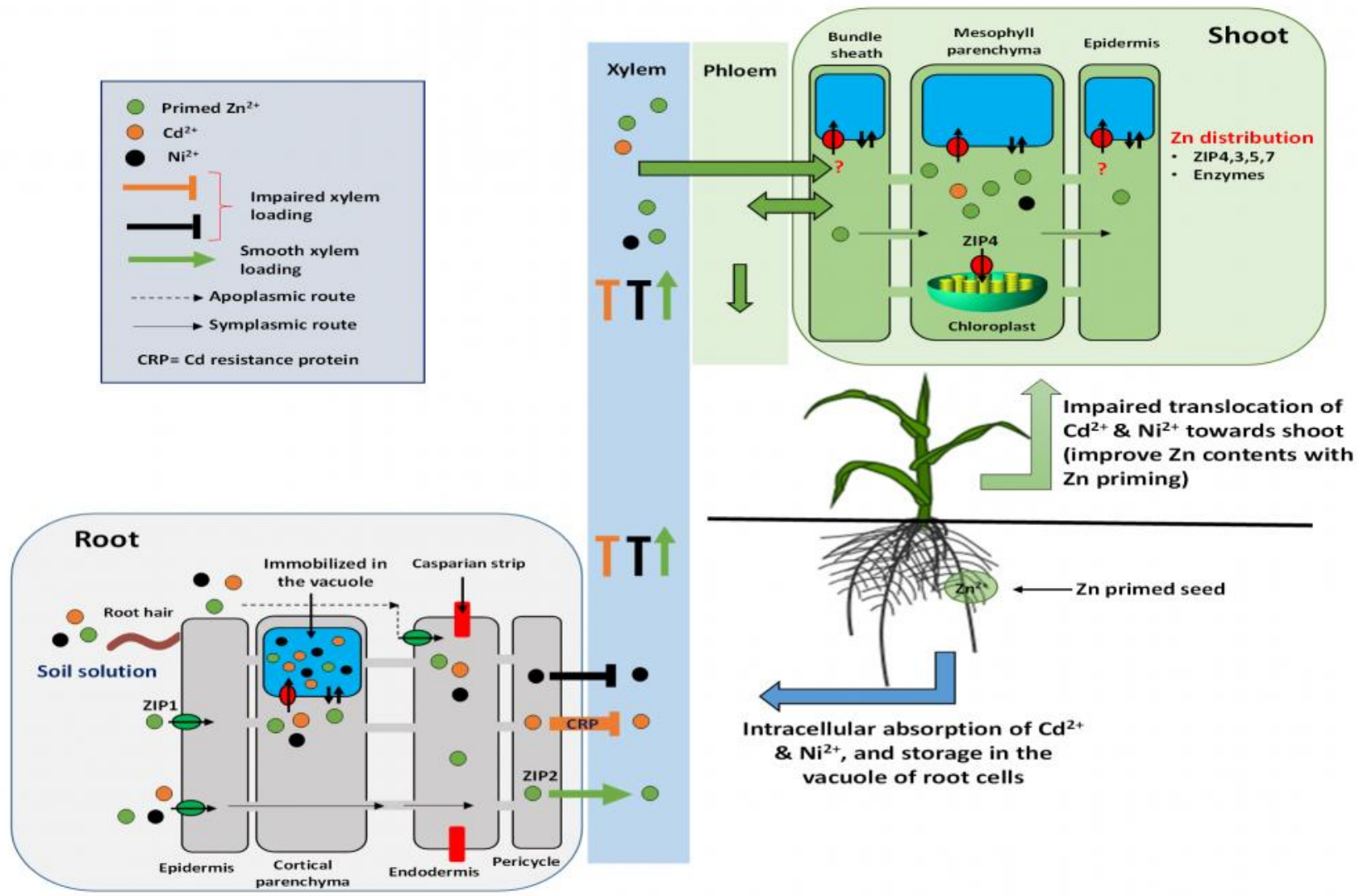

Figure 3. A schematic diagram of uptake and translocation of $\mathrm{Zn}, \mathrm{Cd}$ and Ni from root-to-shoot mediated by $\mathrm{Zn}$ priming. Plant uptake them in the form of $\mathrm{Zn}^{2+}, \mathrm{Cd}^{2+}$ and $\mathrm{Ni}^{2+}$ from soil solution; due to their equivalent valence charge they can share common transport systems and/or translocate via specific transporter per se. In the root cells, a considerable portion of $\mathrm{Cd}$ and $\mathrm{Ni}$ can be absorbed in the intracellular or immobilize in the vacuole by means of $\mathrm{Zn}$ availability. Furthermore, $\mathrm{Zn}$ priming can impair the xylem loading of $\mathrm{Cd}$ and Ni owing to its antagonistic affect or other factors, i.e. plant $\mathrm{Cd}$ resistance protein. Hence, $\mathrm{Zn}$ priming improves $\mathrm{Zn}$ concentration in shoot but not analogous heavy metals, for instance, $\mathrm{Cd}$ and $\mathrm{Ni}$ translocation from root-to-shoot.

Table 2. Maize seedling morphological attributes and SPAD value mediated by $\mathrm{Zn}$ and water primed seeds along with heavy metals $(\mathrm{Cd}$ and $\mathrm{Ni})$ contamination.

\begin{tabular}{|c|c|c|c|c|c|c|c|c|c|}
\hline 跣 & & 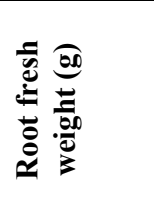 & 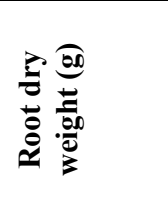 & 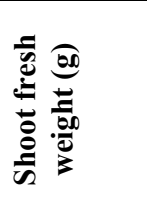 & 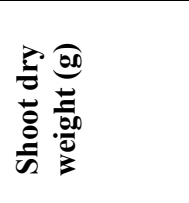 & 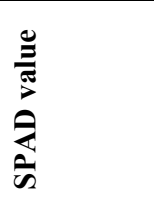 & ș & 己 & 治莺 \\
\hline \multirow{4}{*}{ 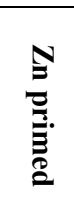 } & CK & $6.54 \pm 1.2^{\mathrm{a}}$ & $2.55 \pm 0.6^{\mathrm{a}}$ & $3.20 \pm 0.3^{\mathrm{ab}}$ & $0.47 \pm 0.00^{\mathrm{abc}}$ & $32.67 \pm 3.8^{\mathrm{a}}$ & $0.45 \pm 0.09^{\mathrm{c}}$ & $0.17 \pm 0.05^{\mathrm{b}}$ & $0.41 \pm 0.30^{\mathrm{bc}}$ \\
\hline & $\mathrm{Zn}$ & $4.22 \pm 1.3^{\mathrm{a}}$ & $1.15 \pm 0$ & $2.81 \pm$ & $0.38+$ & 32.67 & $1.94 \pm 0.06^{\mathrm{a}}$ & $0.26 \pm 0.05^{\mathrm{b}}$ & $0.16 \pm 0.08^{c}$ \\
\hline & $\mathrm{Cd}$ & $6.45 \pm 0.6^{\mathrm{a}}$ & $1.77 \pm 0.2 \mathrm{ab}$ & $2.51 \pm 0.3^{\mathrm{b}}$ & $0.36 \pm 0.30^{\text {cd }}$ & $32.07 \pm 2.5^{\mathrm{a}}$ & $1.48 \frac{\overline{\mathrm{b}}}{\mathrm{b}} .31^{\mathrm{a}}$ & $0.21 \pm 0.03^{\mathrm{b}}$ & $0.24 \pm 0.07^{\mathrm{c}}$ \\
\hline & $\mathrm{Ni}$ & $6.55 \pm 1.0^{\mathrm{a}}$ & $1.94+0.3 \mathrm{ab}$ & $3.31 \pm 0.3^{\mathrm{ab}}$ & $0.45 \pm 0.03^{\mathrm{abcd}}$ & $29.27 \pm 1.9^{\mathrm{a}}$ & $1.4 \frac{7+0.19^{\mathrm{a}}}{\mathrm{b}}$ & $0.21 \pm 0.02^{b}$ & $0.23 \pm 0.01^{\mathrm{c}}$ \\
\hline \multirow{3}{*}{ 这 } & CK & $4.30 \pm 1.0^{\mathrm{a}}$ & $1.51 \pm 0.4^{b}$ & $2.61 \pm 0.2^{\mathrm{ab}}$ & $0.36 \pm 0.03^{\mathrm{d}}$ & $28.77 \pm 3.1^{\mathrm{a}}$ & $0.65 \pm 0.23^{\mathrm{c}}$ & $0.21_{\frac{\mathrm{b}}{ \pm}} 0.06^{\mathrm{a}}$ & $0.87 \pm 0.24^{\mathrm{ab}}$ \\
\hline & $\mathrm{Zn}$ & $6.14 \pm 1.2^{\mathrm{a}}$ & $1.95 \pm 0.4 \mathrm{ab}$ & $3.30 \pm 0.1^{\mathrm{ab}}$ & $0.48 \pm 0.01^{\mathrm{ab}}$ & $34.35 \pm 2.3^{\mathrm{a}}$ & $0.87 \underset{\mathrm{c}}{ \pm 0.22^{\mathrm{b}}}$ & $0.40+0.18^{\mathrm{a}}$ & $0.34 \pm 0.10^{\mathrm{bc}}$ \\
\hline & $\mathrm{Cd}$ & $3.63 \pm 0.1^{\mathrm{a}}$ & $1.04 \pm 0.0^{\mathrm{b}}$ & $2.95 \pm 0.2^{\mathrm{ab}}$ & $0.38 \pm 0.02^{\mathrm{bcd}}$ & $31.12 \pm 1.4^{\mathrm{a}}$ & $0.52 \pm 0.25^{\mathrm{c}}$ & $0.39 \frac{ \pm 0.04^{\mathrm{a}}}{\mathrm{b}}$ & $0.81 \pm 0.37^{\mathrm{a}}$ \\
\hline
\end{tabular}




$\mathrm{Ni} \quad 4.42 \pm 0.8^{\mathrm{a}} \quad 2.13 \pm 0.5^{\mathrm{ab}} \quad 3.42 \pm 0.2^{\mathrm{a}} \quad 0.51 \pm 0.04^{\mathrm{a}} \quad 33.8 \pm 1.9^{\mathrm{a}} \quad 0.25 \pm 0.04^{\mathrm{c}} \quad 0.21 \pm 0.04^{\mathrm{b}} \quad 0.55 \pm 0.10 \mathrm{~b}$

${ }^{\mathrm{a}}$ Means followed by similar letter(s) do not differ significantly according to LSD (root fresh weight, root dry weight, shoot fresh weight, shoot dry weight, SPAD, Zn translocation factor, Cd translocation factor and Ni translocation factor value 1.49, 0.66, 0.41, 0.05, 3.57. $0.68,0.14$ and 0.58 respectively) $(\mathrm{P} \leq 0.05)$

Conclusion: On behalf of our research findings, conclusively seed priming with $\mathrm{Zn}$ is an applicable approach not only to improve $\mathrm{Zn}$ nutrition and but also to suppress the translocation of heavy metals, for instance, $\mathrm{Cd}$ and $\mathrm{Ni}$ in contaminated soils reducing their deleterious effects on plant and human health, ultimately. However, underlying molecular signaling pathways in heavy metal translocation mediated by $\mathrm{Zn}$ priming remains open to be further studied.

Acknowledgements: Authors are highly indebted to Ayub Agricultural Research Institute (AARI), Pakistan for providing the seed of maize variety Malka-2016 and University of Agriculture, Faisalabad-38040, Pakistan for providing research facilities.

\section{REFERENCES}

Alloway, B. J. (2008). Zinc in soils and crop nutrition. $2^{\text {nd }}$ Ed. IZA and IFA, Brussels, Belgium and Paris, France.

Afzal, I., M. A. Noor, M. A. Bakhtavar, A. Ahmad and Z. Haq (2015). Improvement of spring maize performance through physical and physiological seed enhancements. Seed Sci. Technol. 43: 238249.

Afzal, S., N. Akbar, Z. Ahmad, Q. Maqsood, M. Iqbal and M. Aslam (2013). Role of seed priming with zinc in improving the hybrid maize (Zea mays L.) yield. Am. J. Agric. Environ. Sci. 13: 301-306.

Aremu, D. A., and S. Meshitsuka (2005). Accumulation of aluminum by primary cultured astrocytes from aluminum amino acid complex and its apoptotic effect. Brain Res. 1031: 284-296.

Banakar, R., A. Fernandez, P. Díaz-Benito, J. Abadia, T. Capell and P. Christou (2017). Phytosiderophores determine thresholds for iron and zinc accumulation in biofortified rice endosperm while inhibiting the accumulation of cadmium. J. Exp. Bot. 68: 4983-4995.

Chen, Y., D. Chen, and Q. Liu (2017). Exposure to a magnetic field or laser radiation ameliorates effects of $\mathrm{Pb}$ and $\mathrm{Cd}$ on physiology and growth of young wheat seedlings. J. Photochem. Photobiol. 169: 171-177.

Cioccio, S., Y. Gopalapillai, T. Dan and B. Hale (2017). Effect of liming on nickel bioavailability and toxicity to oat and soybean grown in field soils containing aged emissions from a nickel refinery. Environ. Toxicol. Chem. 36: 1110-1119.
DalCorso, G., E. Fasani, A. Manara, G. Visioli and A. Furini (2019). Heavy metal pollutions: state of the art and innovation in phytoremediation. Int. J. Mol. Sci. 20: 3412.

De Oliveira, V. H., I. Ullah, J. M. Dunwell and M. Tibbett (2020). Mycorrhizal symbiosis induces divergent patterns of transport and partitioning of $\mathrm{Cd}$ and $\mathrm{Zn}$ in Populus trichocarpa. Environ. Exp. Bot. 171:103925.

de Souza Guilherme, M. d. F., H. M. de Oliveira and E. da Silva (2015). Cadmium toxicity on seed germination and seedling growth of wheat Triticum aestivum. Acta Scientiarum. Biol. Sci. 37: 499-504.

De Vos, B., S. Lettens, B. Muys and J. A. Deckers (2007). Walkley-Black analysis of forest soil organic carbon: recovery, limitations and uncertainty. Soil Use Manag. 23: 221-229.

Feigl, G., N. Lehotai, Á. Molnár, A. Ördög, M. RodríguezRuiz, J. M. Palma, F. J. Corpas, L. Erdei and Z. Kolbert (2015). Zinc induces distinct changes in the metabolism of reactive oxygen and nitrogen species (ROS and RNS) in the roots of two Brassica species with different sensitivity to zinc stress. Ann. Bot. 116: 613-625.

Gallego, S. M., L. B. Pena, R. A. Barcia, C. E. Azpilicueta, M. F. Iannone, E. P. Rosales, M. S. Zawoznik, M. D. Groppa and M. P. Benavides, (2012). Unravelling cadmium toxicity and tolerance in plants: insight into regulatory mechanisms. Environ. Exp. Bot. 83: 33-46.

Hajiboland, R. and F. Amirazad (2010). Growth, photosynthesis and antioxidant defense system in Zn-deficient red cabbage plants. Plant, Soil Environ. 56: 209-217.

Hseu, Z.-Y. (2004). Evaluating heavy metal contents in nine composts using four digestion methods. Biores. Tech. 95: 53-59.

Ishfaq, M., A. Kiran, A. Khaliq, S. A. Cheema, I. A. Alaraidh, N. Hirotsu and A. Wakeel (2018). Zinc Biofortified Wheat Cultivar Lessens Grain Cadmium Accumulation under Cadmium Contaminated Conditions. Int. J. Agric. Biol. 20: 2842-46.

Johnson, R. A. and G. K. Bhattacharyya (2019). "Statistics: principles and methods," John Wiley \& Sons Inc. United States. ISBN: 978-1-11949711-0

Joy, E. J. M., A. J. Stein, S. D. Young, E. L. Ander, M. J. Watts and M. R. Broadley (2015). Zinc-enriched 
fertilisers as a potential public health intervention in Africa. Plant Soil. 389: 1-24.

Kasim, W. A. (2007). Physiological consequences of structural and ultra-structural changes induced by $\mathrm{Zn}$ stress in Phaseolus vulgaris. I. Growth and photosynthetic apparatus. Int. J. Bot. 3: 15-22.

Köleli, N., Eker, S., and Cakmak, I. (2004). Effect of zinc fertilization on cadmium toxicity in durum and bread wheat grown in zinc-deficient soil. Environ. Pollut. 131: 453-459.

Ma, X., H. Sharifan, F. Dou and W. Sun (2020). Simultaneous reduction of arsenic (As) and cadmium $(\mathrm{Cd})$ accumulation in rice by zinc oxide nanoparticles. Chem. Engin. J. 384: 123802.

Martha-Paz, A. M., D. Eide, D. Mendoza-Cózatl, N. A. Castro-Guerrero and E. T. Aréchiga-Carvajal (2019). Zinc uptake in the Basidiomycota: Characterization of zinc transporters in Ustilago maydis. Mol. Memb. Bio. 35: 39-50.

Mohseni, R., S. M. Ghaderian, and H. Schat (2019). Nickel uptake mechanisms in two Iranian nickel hyperaccumulators, Odontarrhena bracteata and Odontarrhena inflata. Plant Soil 434: 263-269.

Mohsin, A. U., A. U. H. Ahmad, M. Farooq and S. Ullah (2014). Influence of zinc application through seed treatment and foliar spray on growth, productivity and grain quality of hybrid maize. J. Ani. Plant Sci. 24: 1494-1503.

Mondal, S. and B. Bose (2019). Impact of micronutrient seed priming on germination, growth, development, nutritional status and yield aspects of plants. J. Plant Nutri. 42: 2577-2599.

Moustakas, N. K., A. Akoumianaki-Ioannidou, and P. E. Barouchas (2011). The Effects of Cadmium and Zinc Interactions on the Concentration of Cadmium and Zinc in Pot Marigold ('Calendula officinalis' L.). Aust. J. Crop Sci. 5: 277-282

Murtaza, G., W. Javed, A. Hussain, M. Qadir, and A. Aslam (2017). Soil-applied zinc and copper suppress cadmium uptake and improve the performance of cereals and legumes. Int. J. Phytoremed., 19: 199-206.

Page, V. and U. Feller. 2015. Heavy Metals in Crop Plants: Transport and Redistribution Processes on the Whole Plant Level. Agron. 5: 447-463

Page, A., R. Miller, and D. Jeeney (1982). Methods of soil analysis, part 2: Chemical and mineralogical properties. Am. Soc. Agron. Soil Sci. Soc. Am. Inc. Madison. Wisconsin, USA.

Palusińska, M., A. Barabasz, K. Kozak, A. Papierniak, K. Maślińska and D. M. Antosiewicz (2020). Zn/Cd status-dependent accumulation of $\mathrm{Zn}$ and $\mathrm{Cd}$ in root parts in tobacco is accompanied by specific expression of ZIP genes. BMC Plant Bio. 20: 37.

Paparella, S., S. S. Araújo, G. Rossi, M. Wijayasinghe, D. Carbonera and A. Balestrazzi, (2015). Seed priming: state of the art and new perspectives. Plant cell Rep. 34: 1281-1293.

Qaswar, M., S. Hussain and Z. Rengel (2017). Zinc fertilisation increases grain zinc and reduces grain lead and cadmium concentrations more in zinc-biofortified than standard wheat cultivar. Sci. Total Environ. 605: 454-460.

Qayyum, S., S. A. Majid, A. Bibi, A. Ulfat, K. Khanum, A. Munir, S. Nisar, S. Aziz and N. Mumtaz (2018). Effect of seed priming with hormonal combinations on morphological and biochemical attributes of maize seedlings. Phton-Int. J. Exp. Bot. 87: 191-197.

Rashid, A., H. Ram, C.-Q. Zou, B. Rerkasem, A. P. Duarte, S. Simunji, A. Yazici, S. Guo, M. Rizwan and R. S. Bal (2019). Effect of zinc-biofortified seeds on grain yield of wheat, rice, and common bean grown in six countries. J. Plant Nutri. Soil Sci. 182: 791-804.

Rizwan, M., S. Ali, B. Ali, M. Adrees, M. Arshad, A. Hussain, M. Z. ur Rehman, and A. A. Waris (2019). Zinc and iron oxide nanoparticles improved the plant growth and reduced the oxidative stress and cadmium concentration in wheat. Chemosphere. 214: 269-277.

Sabir, M., A. Ghafoor, M. Zia-ur-Rehman, H. R. Ahmad and T. Aziz (2011). Growth and metal ionic composition of Zea mays as affected by nickel supplementation in the nutrient solution. Int. J. Agri. Bio. 13: 186-190

Santos, F. M., L. P. Mazur, D. A. Mayer, V. J. P. Vilar and J. C. M. Pires (2019). Inhibition effect of zinc, cadmium, and nickel ions in microalgal growth and nutrient uptake from water: An experimental approach. Chem. Engin. J. 366: 358-367.

Sarwar, N., S. S. Malhi, M. H. Zia, A. Naeem, S. Bibi, and G. Farid (2010). Role of mineral nutrition in minimizing cadmium accumulation by plants. J. Sci. Food Agri. 90: 925-937.

Sbartai, H., M. R. Djebar, R. Rouabhi, I. Sbartai, and H. Berrebbah (2011). Antioxidative response in tomato plants Lycopersicon esculentum L. roots and leaves to zinc. American-Eurasian J. Toxicol. Sci. 3: 41-46.

Shiyu, Q. I. N., L. I. U. Hongen, N. I. E. Zhaojun, Z. Rengel, G. A. O. Wei, L. I. Chang and Z. Peng (2020). Toxicity of cadmium and its competition with mineral nutrients for uptake by plants: A review. Pedosphere. 30, 168-180.

Simmons, R. W., P. Pongsakul, R. L. Chaney, D. Saiyasitpanich, S. Klinphoklap and W. Nobuntou (2003). The relative exclusion of zinc and iron from rice grain in relation to rice grain cadmium as compared to soybean: Implications for human health. Plant Soil. 257: 163-170.

Singh, S., P. Parihar, R. Singh, V.P. Singh, and S.M. 
Prasad. 2016. Heavy metal tolerance in plants: Role of transcriptomics, proteomics, metabolomics, and ionomics. Front. Plant Sci. 6: 1143.

Soltanpour, P. N. (1985). Use of ammonium bicarbonate DTPA soil test to evaluate elemental availability and toxicity. Commun. Soil Sci. Plant Anal. 16: 323-338.

Syam, N., T. Wardiyati, M. D. Maghfoer, E. Handayanto, B. Ibrahim and A. Muchdar (2016). Effect of accumulator plants on growth and nickel accumulation of soybean on metal-contaminated soil. Agri. Agril. Sci. Proc. 9: 13-19.

Venkatachalam, P., M. Jayaraj, R. Manikandan, N. Geetha, E. R. Rene, N. C. Sharma and S. V. Sahi (2017). Zinc oxide nanoparticles (ZnONPs) alleviate heavy metal-induced toxicity in Leucaena leucocephala seedlings: a physiochemical analysis. Plant Physio. Biochem.
110: 59-69.

Wang, Q. L., L. T. Zhang, J. H. Zou, D. H. Liu, and J. Y. Yue (2014). Effects of cadmium on root growth, cell division and micronuclei formation in root tip cells of Allium cepa var. agrogarum L. Phyton Int. J. Exp. Bot. 83: 291-298.

WHO. (2009). "Global health risks: mortality and burden of disease attributable to selected major risks," World Health Organization.

Yourtchi, M. S., and H. R. Bayat (2013). Effect of cadmium toxicity on growth, cadmium accumulation and macronutrient content of durum wheat (Dena CV.). Int. J. Agri. Crop Sci. 6: 1099-1103.

Yusuf, M., Q. Fariduddin, S. Hayat and A. Ahmad (2011). Nickel: an overview of uptake, essentiality and toxicity in plants. Bull. Environ. Contam. Toxicol. 86: 1-17. 